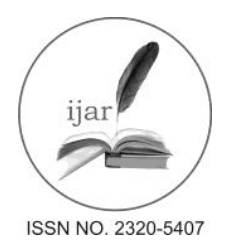

Journal homepage: http://www.journalijar.com

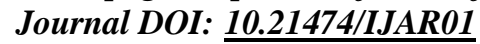

INTERNATIONAL JOURNAL

OF ADVANCED RESEARCH

RESEARCH ARTICLE

\title{
CLINICAL MANAGEMENT OF ADHD WITH COMPARATIVE STUDY OF MANDUKAPARNYADI YOGA AND MATRAVASTI.
}

\section{Dr..Vishala Turlapati, Dr. Abhimanyu Kumar.}

1. M.D.,PhD (AYU), Professor \&Head, P.G. Department of prasuthi tantra, Yashwanth Ayurvedic college, Kodoli, Kolhapur.

2. M.D (Kaumarbhritya), MSc (Psy), DCA, CPHS (USA), Ph.D(Ay.), Director AIIMS,Ayurveda, New Delhi.

\section{Manuscript Info}

Manuscript History:

Received: 12 March 2016

Final Accepted: 22 May 2016

Published Online: May 2016

Key words:

ADHD, DSMIV, Vanderbilt scale,

Douhridavamana, Dopamine,

pranavata,,Matravasti

*Corresponding Author

Dr.. Vishala Turlapati.

\section{Abstract}

Attention Deficit Hyperactivity Disorder (ADHD) probably accounts for more child psychiatric outpatients than any other single disorder. It is estimated that $3-7 \%$ of school -age children have the disorder. .

Materials and Methods:- A randomised double blind placebo control study was conducted.. divided in 3 equal groups. Children between 6-15 years were considered for study. Vanderbilt Diagnostic Parent Rating Scale is used for assessment of core symptoms before and after treatment.

Results:- Group A and Group B showed significant improvement in Inattention, hyperactivity and impulsivity. These results are indicating Matra vasti combined with drug is effective in Core symptoms of ADHD. Academic and classroom behaviour is having marked response with Drug alone .

Conclusion:- Mandukaparnyadi yoga is effective in management of ADHD. Application of Matravasti offers some added advantage when administered along with Mandukaparnyadi yoga. Further extensive study is needed with a larger sample size to establish more authentically the present study result.

Copy Right, IJAR, 2016. All rights reserved.

\section{Introduction:-}

Attention Deficit Hyperactivity Disorder (ADHD) probably accounts for more child psychiatric outpatients than any other single disorder. It is estimated that $3-7 \%$ of school -age children have the disorder, with much higher rates reported in some studies. The current estimation is that, approximately 2 million children across the United States of America are suffering with ADHD. In a practical sense in any given classroom of 25 to 30 children, there is likely to be at least one child who has ADHD.(1)

A person with attention deficit disorder faces a difficult but not insurmountable task ahead. The childhood syndrome primarily consists of three core symptoms Inattention (concentration, difficulties, short attention span, distractibility), impulsivity, (impatience, acting without thinking) and Hyperactivity (restlessness, always on the go).The long term progress or out-come of children with ADHD has drawn considerable attention.(2)(3)

Children with ADHD are typically:-

Impulsive, forgetful, restless to the point of disruption, prone to foil, unable to follow through in tasks, unpredictable, moody.(4) 
Etiological theories include neurobilogical conditions,genetic and heredeterary factors, prenatal influences,nutritional factors and deficiencies,environmental influences.(5)(6)

\section{Difficulties in tasks for ADHD children are identified in six areas:-}

1. Flexibility: unable to easily shift from one mindset or strategy to another.

2. Organization: unable to anticipate both needs and problems.

3. Planning, particularly goal setting.

4. Working or short-term memory: difficulty in receiving, storing and then retrieving information.

5. Separating affect from cognition: difficulty detaching emotions from reasons.

6. Inhibiting and regulating verbal and motoric action, impulsive, anxious, and impatient.

In Ayurvedic texts, no specific term is given for ADHD. Symptoms of ADHD like inattention, hyperactivity and impulsivity may be considered as due to pathology in manas and vitiation of Vata dosha. The manas is considered as major factor for attention. Among tridoshas vata is considered as controller and motivator of manas(.7) In Ayurveda childhood psychological disorders are not dealt independently. Scattered references can be compiled relating the saririka and manasika traits. some of the manasika and saririka prakrithis shows some related symptoms to ADHD. vatavriddhi and kshaya along with sadhaka pitta vriddhi leads to manovaha sroto vaigunya leading to the development of ADHD. This can be understood as reduced dopamine secretion (vatakshaya), hyperperfusion of dopamine transporter density in striatum in occipital cortex (vata and pitta vriddhi).

Modern science believes in the involvement of pre frontal lobes in the pathogenesis and dysfunction of Neurotransmitters like Dopamine.

\section{Materials and Methods:-}

A randomised double-blind placebo controlled study in the age group of 6-15 years divided in 3 groups with 20 children in each group.

\section{Selection of cases:-}

Children for the present study were screened initially from different schools around Kolhapur. They are randomly divided in to three groups.

Registered at Yaswanth Ayurvedic medical college hospital, kodoli, Kolhapur.

Initially children were screened with ADHD pre-assessment format as per DSM-IV criteria, with the help of school teachers. After diagnosing as ADHD child, Vanderbilt parent diagnostic rating scale was used as assessment scale before and after treatment.

Total 68 children were registered and out of which 3 were dropped out and 5 children were withdrawn from study because of below average IQ.

Group A:- This group of 20 children were given Matravasti and Ayurvedic compound Mandukaparnyadi yoga. (MPY) in the form of syrup.

Group B:- This group of 20 children were given only Mandukaparnyadiyoga (MPY-SYRUP)

Group C:- This Group of 20 children were given Placebo syrup.

\section{Diagnostic Criteria:-}

Initially with DSM-IV Criteria screening is done, followed by Vanderbilt Diagnostic Parent Assessment Scale.

\section{Assessment Criteria:-}

1. DSM-IV

2. IQ assessment by "Draw-A-Man test"

A pre assessment questionnaire was made on the basis of DSM-IV Criteria, which included 18 questions, which were filled by school teachers. 
Vanderbilt scale which contains 47 points related to behaviour and two sections for academic and classroom performance were filled by parents.

b) For I.Q assessment-

IQ assessment by Draw-A-Man test.

\section{Selection of Drug:-}

A Hypothetical compound drug containing 3 herbs were selected for the present study and were named as Mandukaparnyadi yoga (MPY). This was prepared in the form of syrup.

The prayojyanga (useful parts) of the herbs were collected in dry form and prepared in the process of syrup in the Yashwanth Ayurvedic College Pharmacy, Kodoli, and Kolhapur.

\section{Dose \& Duration:-}

- 10-ml of syrup up from 6-10 years

- $\quad$ 15-ml from 10-15 years.

Twice daily after food for 3 months. Follow up was done once in 15 days. Parents were informed to report in case of any side effects.

\section{Placebo:-}

The placebo for the study was also in the form of syrup with same colour and consistency as study drug, containing plain sugar syrup. Same dose was adopted and it is coded as MPY1.

Matra vasti :( Aswagandhaghrita):-

Ashwagandha ghrita is administered through rectal route.

Dosage:-

25 mlTime;- after morning meal for 9 days for 3 cycles. Follow up was done once in 15 days. Parents were informed to report in case of any side effects

Data were analysed using Statistical software SPSS Version 16 and paired t tests were applied.

\section{Assessment of progress:-}

Marked Improvement (100 - $75 \%)$

Moderate Improvement (75 - 50\%)

No Improvement $(<50 \%)$ observed in core symptoms.

\section{Observation \& results:-}

Maximum number of children belongs to 10-13 years of age group. Though both the sex was registered male children were more in number. Socio-economic status of maximum percent tage (40 percent) was either lower middle class or lower class. 0 percent patients were from joint families. Parent's education background was not good enough. Vata-pittaja prakriti patients were more in number dominated by Rajasik-Tamasik manasika prakriti. More than 50 percent mothers gave the retrospective history of Douhridavamana (non-fulfillment of maternal cravings). Some of the history revealed physical abuse during Antenatal period. The mile stone development was unaffected. 66 Percent of patients gave the history of poor parent -child relationship and peer relationship. Maximum patients were seen with average IQ. Assessment criteria were based on the improving score of inattention, Hyperactivity, impulsivity based on Vanderbilt parent -rating scale. Academic performance, classroom behaviour were also assessed by interacting with teachers before and after treatment.

Incidence of age-table no.1:-

\begin{tabular}{|c|c|c|c|c|c|c|c|c|c|}
\hline \multirow[t]{2}{*}{ S.No. } & \multirow[t]{2}{*}{ Age } & \multicolumn{2}{|c|}{ Group A } & \multicolumn{2}{|c|}{ Group B } & \multicolumn{2}{|c|}{ Group C } & \multicolumn{2}{|c|}{ Total } \\
\hline & & No. & $\%$ & No. & $\%$ & No. & $\%$ & No. & $\%$ \\
\hline 1. & $6-9$ & 01 & 05.00 & 06 & 30.00 & 00 & 00.00 & 07 & 11.67 \\
\hline 2. & $10-13$ & 17 & 85.00 & 14 & 70.00 & 20 & 100.00 & 51 & 85.00 \\
\hline 3. & $14-15$ & 02 & 10.00 & 00 & 00.00 & 00 & 00.00 & 02 & 03.33 \\
\hline & tal & 20 & 100.00 & 20 & 100.00 & 20 & 100.00 & 60 & 100.00 \\
\hline
\end{tabular}

$85 \%$ of Children were between age group $10-13$ years. $(n=20)$ 
Incidence of sex table no.2:-

\begin{tabular}{|c|c|c|c|c|c|c|c|c|c|}
\hline \multirow[t]{2}{*}{ S.No. } & \multirow[t]{2}{*}{ Sex } & \multicolumn{2}{|c|}{ Group A } & \multicolumn{2}{|c|}{ Group B } & \multicolumn{2}{|c|}{ Group C } & \multicolumn{2}{|c|}{ Total } \\
\hline & & No. & $\%$ & No. & $\%$ & No. & $\%$ & No. & $\%$ \\
\hline 1. & Male & 17 & 85.00 & 14 & 70.00 & 13 & 65.00 & 44 & 73.33 \\
\hline 2. & Female & 03 & 15.00 & 06 & 30.00 & 07 & 35.00 & 16 & 26.67 \\
\hline & Total & 20 & 100.00 & 20 & 100.00 & 20 & 100.00 & 60 & 100.00 \\
\hline
\end{tabular}

$\mathrm{N}=20$

Incidence of education of father table no.3:-

\begin{tabular}{|c|c|c|c|c|c|c|c|c|c|}
\hline S.No. & \multirow{2}{*}{$\begin{array}{c}\text { Education of } \\
\text { Father }\end{array}$} & \multicolumn{2}{|c|}{ Group A } & \multicolumn{2}{c|}{ Group B } & \multicolumn{2}{c|}{ Group C } & \multicolumn{2}{c|}{ Total } \\
\cline { 3 - 9 } & No. & \% & No. & \% & No. & \% & No. & \% \\
\hline 1. & Primary & 01 & 05.00 & 04 & 20.00 & 03 & 15.00 & 08 & 13.33 \\
\hline 2. & High school & 07 & 35.00 & 08 & 40.00 & 06 & 30.00 & 21 & 35.00 \\
\hline 3. & Senior Sec. & 02 & 10.00 & 01 & 05.00 & 08 & 40.00 & 11 & 18.33 \\
\hline 4. & Graduation & 04 & 20.00 & 03 & 15.00 & 01 & 05.00 & 08 & 13.33 \\
\hline 5. & Uneducated & 06 & 30.00 & 04 & 20.00 & 02 & 10.00 & 12 & 20.00 \\
\hline & Total & $\mathbf{2 0}$ & $\mathbf{1 0 0 . 0 0}$ & $\mathbf{2 0}$ & $\mathbf{1 0 0 . 0 0}$ & $\mathbf{2 0}$ & $\mathbf{1 0 0 . 0 0}$ & $\mathbf{6 0}$ & $\mathbf{1 0 0 . 0 0}$ \\
\hline
\end{tabular}

$\mathrm{N}=20$

Incidence of shareera prakriti table.no.4:-

\begin{tabular}{|c|c|c|c|c|c|c|c|c|c|}
\hline \multirow{2}{*}{ S.No. } & \multirow{2}{*}{ Shareera Prakriti } & \multicolumn{2}{|c|}{ Group A } & \multicolumn{2}{c|}{ Group B } & \multicolumn{2}{c|}{ Group C } & \multicolumn{2}{c|}{ Total } \\
\cline { 3 - 9 } & & No. & \% & No. & \% & No. & \% & No. & $\%$ \\
\hline 1. & Vata-Pittaja & 13 & 65.00 & 10 & 50.00 & 11 & 55.00 & 34 & 56.67 \\
\hline 2. & Pitta-Kaphaja & 02 & 10.00 & 00 & 00.00 & 03 & 15.00 & 05 & 08.33 \\
\hline 3. & Kapha-Pittaja & 03 & 15.00 & 00 & 00.00 & 02 & 10.00 & 05 & 08.33 \\
\hline 4. & Vata-Kaphaja & 00 & 00.00 & 04 & 20.00 & 00 & 00.00 & 04 & 06.67 \\
\hline 5. & Pitta-Vataja & 02 & 10.00 & 05 & 25.00 & 01 & 05.00 & 08 & 13.33 \\
\hline 6. & Kapha-Vataja & 00 & 00.00 & 01 & 05.00 & 03 & 15.00 & 04 & 06.67 \\
\hline 7. & Tridoshaja & 00 & 00.00 & 00 & 00.00 & 00 & 00.00 & 00 & 00.00 \\
\hline & Total & $\mathbf{2 0}$ & $\mathbf{1 0 0 . 0 0}$ & $\mathbf{2 0}$ & $\mathbf{1 0 0 . 0 0}$ & $\mathbf{2 0}$ & $\mathbf{1 0 0 . 0 0}$ & $\mathbf{6 0}$ & $\mathbf{1 0 0 . 0 0}$ \\
\hline
\end{tabular}

$\mathrm{N}=20$

Maximum number of patients belong to Vata-Pittaja prakriti (56.67\%), followed by pitta-vataja prakriti (13.33\%).

Incidence of manasika prakriti table no.5:-

\begin{tabular}{|c|c|c|c|c|c|c|c|c|c|}
\hline \multirow{2}{*}{ S.No. } & \multirow{2}{*}{ Manasika Prakriti } & \multicolumn{2}{|c|}{ Group A } & \multicolumn{2}{|c|}{ Group B } & \multicolumn{2}{|c|}{ Group C } & \multicolumn{2}{|c|}{ Total } \\
\hline & & No. & $\%$ & No. & $\%$ & No. & $\%$ & No. & $\%$ \\
\hline 1. & Satvika-Rajasika & 00 & 00.00 & 00 & 00.00 & 00 & 00.00 & 00 & 00.00 \\
\hline 2. & Rajasika-Satvika & 00 & 00.00 & 00 & 00.00 & 00 & 00.00 & 00 & 00.00 \\
\hline 3. & Rajasika-Tamasika & 15 & 75.00 & 16 & 80.00 & 11 & 55.00 & 42 & 70.00 \\
\hline 4. & Tamasika-Rajasika & 04 & 20.00 & 04 & 20.00 & 09 & 45.00 & 17 & 28.33 \\
\hline 5. & Satvika-Tamasika & 01 & 05.00 & 00 & 00.00 & 00 & 00.00 & 01 & 01.67 \\
\hline 6. & Tamasika-Satvika & 00 & 00.00 & 00 & 00.00 & 00 & 00.00 & 00 & 00.00 \\
\hline & Total & 20 & 100.00 & 20 & 100.00 & 20 & 100.00 & 60 & 100.00 \\
\hline
\end{tabular}

$\mathrm{N}=20$

Maximum number of patients belongs to Rajasika-Tamasika prakriti (70\%), followed by Tamasika-Rajasika prakriti $(28.33 \%)$. 
Incidence of antenatal complications table no.6:-

\begin{tabular}{|c|c|c|c|c|c|c|c|c|c|}
\hline \multirow{2}{*}{ S.No. } & \multirow{2}{*}{$\begin{array}{c}\text { Antenatal } \\
\text { Complications }\end{array}$} & \multicolumn{2}{|c|}{ Group A } & \multicolumn{2}{|c|}{ Group B } & \multicolumn{2}{|c|}{ Group C } & \multicolumn{2}{|c|}{ Total } \\
\hline & & No. & $\%$ & No. & $\%$ & No. & $\%$ & No. & $\%$ \\
\hline 1. & Anaemia & 04 & 20.00 & 04 & 20.00 & 03 & 15.00 & 11 & 18.33 \\
\hline 2. & $\mathrm{PIH}$ & 01 & 05.00 & 00 & 00.00 & 03 & 15.00 & 04 & 06.66 \\
\hline 3. & Diabetes & 00 & 00.00 & 00 & 00.00 & 00 & 00.00 & 00 & 00.00 \\
\hline 4. & $\mathrm{APH}$ & 00 & 00.00 & 00 & 00.00 & 00 & 00.00 & 00 & 00.00 \\
\hline 5. & Hyperemesis & 01 & 05.00 & 00 & 00.00 & 00 & 00.00 & 01 & 01.67 \\
\hline 6. & $\begin{array}{l}\text { Non-fulfillment of } \\
\text { maternal craving }\end{array}$ & 04 & 20.00 & 07 & 35.00 & 08 & 40.00 & 19 & 31.67 \\
\hline 7. & $\begin{array}{c}\text { Exposure to } \\
\text { toxins/Pesticides }\end{array}$ & 00 & 00.00 & 02 & 10.00 & 00 & 00.00 & 02 & 03.33 \\
\hline 8. & Addictions & 00 & 00.00 & 00 & 00.00 & 00 & 00.00 & 00 & 00.00 \\
\hline 9. & Physical abuse & 01 & 05.00 & 00 & 00.00 & 02 & 10.00 & 03 & 05.00 \\
\hline 10. & Psychological upset & 01 & 05.00 & 00 & 00.00 & 03 & 15.00 & 04 & 06.67 \\
\hline & Total & 20 & 100.00 & 20 & 100.00 & 20 & 100.00 & 60 & 100.00 \\
\hline
\end{tabular}

$\mathrm{N}=20$

The incidence of Non-Fulfillment of Maternal cravings is having highest incidence of $31.67 \%$,though it is not a complication, it is included keeping in view the stressful prenatal condition, followed by $18.33 \%$ of ADHD mothers suffered with Anemia,6.66\% of PIH,3.33\% of exposure to pesticides/toxins, $6.67 \%$ of mothers had history of psychological upset.

In groups A, and B, Statistically significant improvement is seen in the scores of Inattention. $(\mathrm{p}<0.001)$.

Group B is highly significant statistically in the scores of impulsivity $(\mathrm{p}<0.001)$, Group B Showed highest improvement of Above Average Academic performance (85\%), Group A showed 65\% of above average performance.

The results of Performance scale in Reading, Mathematics, and Writing is statistically highly significant in Group A $(\mathrm{p}<0.001)$. The results of Classroom Behaviour are also highly significant statistically $(\mathrm{p}<0.001)$.

Group A and Group B Showed high significance statistically on Academic performance score. ( $<<0.05)$. Group C is statistically insignificant. ( $>0.05)$. Three Groups are statistically Significant in improvement in Class room Behaviour. $(\mathrm{p}<0.05)$.

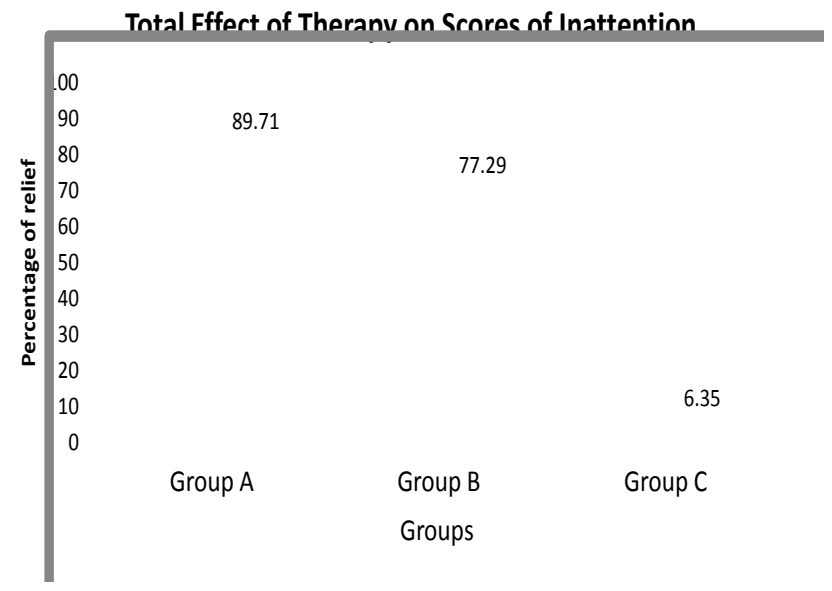




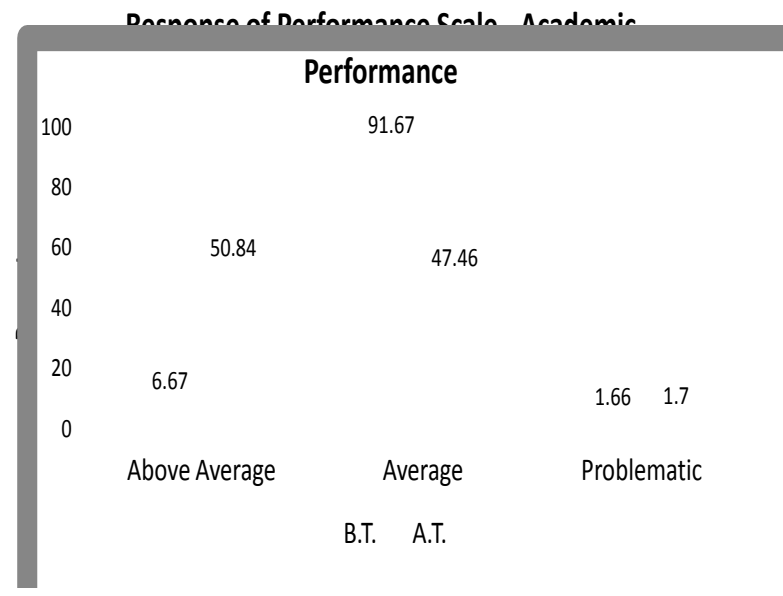

Total effect of therapy on the core symptoms of ADHD (Subjective) table no.7 $\mathbf{n = 2 0}$

\begin{tabular}{|c|c|c|c|c|c|c|c|c|c|}
\hline S.No. & $\begin{array}{c}\text { Degree of } \\
\text { Improvement }\end{array}$ & \multicolumn{2}{|c|}{ Group A } & \multicolumn{2}{|c|}{ Group B } & \multicolumn{2}{|c|}{ Group C } & \multicolumn{2}{|c|}{ Total } \\
\cline { 3 - 10 } & No. & $\mathbf{\%}$ & No. & $\mathbf{\%}$ & No. & $\mathbf{\%}$ & No. & \% \\
\hline 1. & $\begin{array}{c}\text { Marked } \\
\text { Improvement } \\
(100-75 \%)\end{array}$ & 17 & 85.00 & 14 & 70.00 & 01 & 05.00 & 32 & 53.33 \\
\hline 2. & $\begin{array}{c}\text { Moderate } \\
\text { Improvement } \\
(75-50 \%)\end{array}$ & 02 & 10.00 & 03 & 15.00 & 00 & 00.00 & 05 & 05.00 \\
\hline 3. & $\begin{array}{c}\text { No Improvement } \\
(<50 \%)\end{array}$ & 01 & 05.00 & 03 & 15.00 & 19 & 95.00 & 23 & 36.67 \\
\hline \multicolumn{2}{|c|}{ Total } & $\mathbf{2 0}$ & $\mathbf{1 0 0 . 0 0}$ & $\mathbf{2 0}$ & $\mathbf{1 0 0 . 0 0}$ & $\mathbf{2 0}$ & $\mathbf{1 0 0 . 0 0}$ & $\mathbf{6 0}$ & $\mathbf{1 0 0 . 0 0}$ \\
\hline
\end{tabular}

\section{Discussion:-}

Attention deficit Hyperactivity Disorder (ADHD) is the most common neurobehavioural disorder. Children with ADHD suffer with emotional problems and low self esteem. Hyperactive and impulsive children always remain as problem for parents and teachers . ADHD can be understood as Manovahasroto vikara. Children with ADHD may have significantly altered levels of important neurotransmitters in the frontal region of the $b$ rain.

Hyperperfusion of dopamine transporter density in stratum in occipital cortex and dopamine decrease leads to ADHD. Both can be understood as Vata, Pittavriddhi and Vata kshaya. Hyperperfusion and dopamine decrease leads to impulsivity, inattention, distractibility and loss of coordination.

* In modern medicine ADHD is treated with Medications such as stimulants and anti depressants for short term along with Behaviour modification, Family counselling, cognitive behaviour therapy and behavioural intervention programme.

* Stimulant drugs carry risk of Increase aggressive behaviour or hostility.

* Slow growth and weight gain in children.

* Nervousness and sleeplessness.

According to Ayurvedic concept vitiation of tridoshas causes Manovahasrotovaigunya which leads to Rajo \&Tamoguna vaigunya and manovahasroto sanga along with atipravritti.This leads to manovyapara vaigunya leading to loss of Dhriti, Dhee, Smriti and pragnaparadha causing ADHD.(8)The pathological components of ADHD are tridoshaja,raja,tamao manodoshas having mastishka as adhisthana with manovahasrotas dushti in the form of Atipravritti and sanga. The pathology is pranavata vriddhi and kshaya intermittently leading to margavarodha to pranavata , causing decline in pranavata functions leading to manavahasrotovaiguna .(ADHD).(9)

The treatment principle is to clear the obstruction of manovahasrotas and passifying tridoshas in particular vata . Vastichikitsa with medhya rasayanas will be the ideal management.(10) The mandukaparnyadi yoga contains laghu guna and snigdha guna, medhya , rasayana and tridoshahara properties. Laghu guna is srotosodhaka and also having 
positive effects on psyche by improving activeness and provides inspiration. This srotosodhaka property clears the obstruction of manovahasrotas by increasing dopamine secretion and reducing hyperperfusion of frontal areas. The drug is having e effective in the Improvement of the function of Mana and Budhhi i.e. neurocognitive functions.

Aswagandha ghrita matravasti for is selected due to the Neuroprotective and antistress properties. It is also having Nerve Regeneration property, which helps in improving the cognitive functions. It is a potential Vata and Kapha hara, Rasayana drug. All these properties are needed for correcting the pathology of ADHD.. Advantage of injecting drugs through transrectal route is direct absorption from Rectum, colon and small intestine without reacting with digestive enzymes and acids.

Lipid soluble and unionized substances are readily absorbed from the rectum. Vasti may act through the nervous system or through the enteric system. Vasti is the best treatment for Vata as said by Acharya charaka.. It may increase the secretion of local enzyme or neurotransmitters. Vasti influences the normal bacterial flora, thus it increase the endogenous synthesis of Vitamin B12, Vitamin K.

\section{Conclusion:-}

* Douhridavamana seems to be the cause of prenatal maternal stress which may contribute to the development of ADHD

* Low socio economic children are more vulnerable for development of ADHD.

* ADHD Children in spite of above average IQ possess poor academic skills.

* Mandukaparnayadi yoga along with matravasti with Ashwagandha ghrita proved effective in improving the symptoms of inattention and hyperpeactivity with highly significant result. Mandukaparnayadi yoga comparatively gave significant result in the improvement of hyperpeactivity and impulsivity.

* Academic performance improvement and class room behaviour equally proved effective with both vasti and Mandukaparnayadi yoga groups. Significant change was also observed in before and after the treatment in the IQ levels which was assessed b Draw-A-Man square test.

* Further extensive study is needed with a larger sample size to establish more authentically the present study result.

\section{References:-}

1. American Psychiatric Association. (1987). Diagnostic and statistical manual of mental disorders (3rd ed., rev.). Washington, DC: Author.

2. American Psychiatric Association. (1994). Diagnostic and statistical manual of mental disorders (4th ed.). Washington, DC: Author.

3. (American Psychiatric Association 2000)

4. Breen, M. J. (1989). Cognitive and behavioral differences in ADHD boys and girls. Journal of Child Psychology and Psychiatry, 30, 711-716.

5. Millichap JG. Etiologic classification of attention-deficit/hyperactivity disorder. Pediatrics. 2008 Feb; 121(2):e358-65.

6. Biederman, J., Faraone, S. V., Keenan, K., \& Tsuang, M. T. (1991). Evidence of a familial association between attention deficit disorder and major affective disorders. Archives of General Psychiatry, 48, 633-642.

7. Charaka samhita vimana sthana VOL 1 TO IV ,P.V.SHARMA $8 / 22$,Chaukamba orientalia,Varanasi, $8^{\text {th }}$ edition, 2007

8. Kasyapa samhita khila sthana adhyaya 3/72,73,74 ,pandit Hemraj Sharma ,sri satyapal bhishagacharya, Chaukamba Sanskrit sansthan, Varanasi,2009 of Harisree hospital ,2 $2^{\text {nd }}$ edition, 2008.

9. Charaka samhita sareera sthana adhyaya $3 / 23$, agnivesa, Hindi commentary by pt.kasinath shastri and Dr.Gorakh Natha chaturvedi, edition 2007, chaukamba bharati academy, Varanasi.

10. Astanga sanghraha sareera sthana adhyaya 5/20, Vol 1,2 and 3, T.sreekumar. 